\author{
Karol Król \\ University of Agriculture in Krakow \\ Faculty of Environmental Engineering and Land Surveying \\ Department of Spatial Management and Landscape Architecture \\ k.krol@onet.com.pl
}

\title{
INTERNET DOMAINS PROMOTING AGROTOURIST FARMS
}

\begin{abstract}
Many agrotourist farms use the potential of websites to distinguish their offer from others to attract as many guests as possible. However, maintaining a website is connected with a range of costs, e.g. registering the domain and the hosting package. Searching for cost savings, the owners of agrotourist farms often face the dilemma of choosing between a payable website and its free equivalent. The aim of this article is to analyse internet addresses as regards their type and potential, both informative and marketing. The surveys were carried out on a set of 1,121 websites. The analysis included domain names (main names) as well as domain extensions, paying special attention to type and indicating sub-domains at the same time. Division into payable and free was looked for as well. In conclusion, it is shown that the owners of agrotourist farms mostly use national domains, choosing addresses in functional, regional or European domains less frequently. Moreover, they relatively rarely use addresses created on free services. In their place, they choose free sub-domains often created in the domain of the provider hosting a regional (informative) portal or another.
\end{abstract}

Keywords: promotion of agrotourism, internet domain, internet marketing.

\section{INTRODUCTION}

The internet is commonly used in conducting economic activity (SHANG et al. 2017). It allows a quick and massive transfer of information, creating an image and brand, building a community, providing functional communication with the customer as well as being a measure of the efficiency of business activities ( $\mathrm{ZHU}$ \& ZHANG 2010, CHEN \& XU 2017).

An internet domain, often valuable capital for a company, is the basis for every activity on the internet. It identifies the operator and can be a trademark as well as the basis for a marketing strategy. A properly selected name allows a given operator to be distinguished, to point to a line of business, offer an assortment of services, and determine its range of impact (LINDENTHAL 2014, PAWLAK 2014). An attractive internet address can be seen in statistics for website visits which with its preparation can influence the results (BARTOSIAK 2010).

The popularity and number of registered internet domains is increasing at a steady pace. In Poland at the end of 2016, there were 2.5 million domain names maintained by over one million subscribers (WIŚNIEWSKA-SKÓRA 2016). This has generated progress in the internet domain market which is now one of the most dynamically developing in the world. The growing popularity of a domain is one of the results of the fact that websites have become one of the most effective marketing tools (ROGOWSKI 2014, KRÓL et al. 2017).

Agrotourist farms and the other providers of accommodation services in rural areas increasingly willingly use information technologies which improve communication with the customer and are channels for selling services (KRÓL \& WOJEWODZIC 2006, DROZDOWSKA \& DUDA-SEIFERT 2016). Multimedia and computerised marketing tools allow specific tourism services to be created more and more convincingly and remove the inconveniences connected with physical distance from point of purchase and tourism consumption (KACHNIEWSKA 2011). Many owners of agrotourist farms successfully use the potential of websites to distinguish their offer from others and to reach a wider group of customers (KRZYŻANOWSKA 2014, KRÓL 2016a).

Quality (published content and techniques) as well as marketing strategies and a properly selected name decide above all the success of a website. This requires specific costs to be incurred. The owners of agrotourist farms searching for savings and budgetary solutions often face the dilemma of choosing between ordering a website and buying a hosting package (resources of 
the server and software that allows a website to be started) together with registering a payable domain (KRÓL 2015), or using one of the many services that are free of charge. So, the question arises which solution is chosen most frequently and what marketing consequences does it imply.

The aim of the paper is to analyse the internet addresses of agrotourist farms, taking type as well as informative and marketing potential into account. The research hypothesis was posed on the basis of the analysis of K. KRÓL \& D. BEDLA (2014) that a great number of owners of agrotourist farms search for savings and use free hosting services and free internet addresses.

\section{TYPES OF INTERNET DOMAIN - INTRODUCTION}

Every internet address contains a sequence of signs (words) and is constructed hierarchically. The signs constitute labels which are separated from each other by a dot. The labels are ordered from detailed to general. Basically, an internet domain can be divided into the main name and its extension (so-called ending). The domains are divided into these from the highest level described as TLD (Top-Level Domains) local (national, state ones; country code TLD, ccTLD, e.g. domain . $p l$ ) and functional ones also called global (generic TLD, gTLD) attributed to websites that represent various types of activity e.g. .gov (government) (JANC 2015). Moreover, domains of a secondary level can be distinguished (SLD - Second Level Domains), e.g. the national functional domain .com.pl), multilingual domains with national diacritic signs (Internationalized Domain Name, IDN) and also regional domains that usually determine a place or a region with which the given subject is connected, e.g. beskidy.pl.

Many internet addresses belong to the main domain of a higher level one. They are described as 'subdomains' and are used most frequently to differentiate various parts of the given service. For example, the internet address www.krawiec.agroturystyka.pl is a subdomain which belongs to the service agroturystyka.pl. Internet addresses can be also divided into payable that need to be registered and have a subscription fee and those which are free usually created as a subdomain of a given service.

In Poland, domain names registered with the extension .pl are the most popular being the most intuitive for users (WIŚNIEWSKA-SKÓRA \& GNIADEK 2017). The national register of internet names in the domain . $p l$ is managed in Poland by NASK - Scientific and Academic Computer Network (in Polish: Naukowa i Akademicka Sieć Komputerowa), a research institute established in Warsaw. NASK administers the national domain .pl and numerous domains of the second level - functional and regional, however registration can be made exclusively via partners of NASK (KRÓL et al. 2017).

\section{MATERIAL AND METHODS}

The surveys were made on a set of 1,121 active agrotourist farm websites whose addresses were obtained on 1 June 2017 from the following catalogues: 'Onet.pl' (967 addresses from the category Agrotourism) and agroturystyka.pl (154 addresses). The domain names (main names) were analysed as regards recording of labels and the most frequently occurring keywords with significant meaning such as the prefixes or suffixes 'agro', 'agrotourism', 'ranch' or 'homestead' (in Polish: 'agro', 'agroturystyka', 'ranczo' or 'zagroda', respectively). Extensions of domains (endings) as regards their type (national, functional, regional, other) with simultaneous designations of sub-domains were also analysed. The division of domains (hosting) into payable and free of charge was made as well (Table 1). Moreover, model addresses and unfavourable ones in terms of marketing were selected and characterised.

Table 1. Range of individual elements of an internet address

\begin{tabular}{|l|l|}
\hline $\begin{array}{c}\text { Element of an } \\
\text { internet address }\end{array}$ & \multicolumn{1}{c|}{ Range of analysis } \\
\hline $\begin{array}{l}\text { Main name } \\
\text { (label of domain) }\end{array}$ & $\begin{array}{l}\text { record identification - using hyphens, } \\
\text { underlining and others } \\
- \text { use of diacritics } \\
- \text { identification of keywords }\end{array}$ \\
\hline $\begin{array}{l}\text { Extension } \\
\text { (ending) }\end{array}$ & $\begin{array}{l}- \text { identification of a type (national, func- } \\
\text { tional, other) }\end{array}$ \\
& $\begin{array}{l}\text { specification of sub-domains } \\
\text { distinction into free of charge or pay- } \\
\text { able }\end{array}$ \\
\hline
\end{tabular}

Source: author.

\section{RESULTS AND CONCLUSIONS}

The owners of agrotourist farms most frequently use the addresses of various types and levels in the national domain $(. p l)$. There were 982 noted altogether (about $88 \%$ ), 480 of which were binominal names of the type 'etykieta.końcówka' (national domains at the highest level - ccTLD), 432 constituted the subdomains created in the domain of another service (38.5\%) and diacritic signs were noted in two addresses (wojciechówka.pl and agroturystykastrużka.pl). The commercial endings .com or .com.pl. were chosen less frequently by farm owners. There were 115 such addresses altogether (registration of an address in the 
commercial domain may result from the fact that an analogical name in the domain .pl was already reserved). A few addresses were also noted in functional, regional and European domains (Table 2).

Table 2. The type and number of payable domains

\begin{tabular}{|c|l|c|c|}
\hline \multirow{2}{*}{ No. } & \multicolumn{3}{|c|}{ Domain } \\
\cline { 2 - 4 } & \multicolumn{1}{|c|}{ type } & number & $\%$ \\
\hline 1 & $p l$ & 480 & 42.6 \\
\hline 2 & $p l(d)$ & 2 & 0.1 \\
\hline 3 & $e u$ & 37 & 3.3 \\
\hline 4 & com.pl & 42 & 3.7 \\
\hline 5 & com & 73 & 6.6 \\
\hline 6 & info & 3 & 0.3 \\
\hline 7 & info.pl & 4 & 0.4 \\
\hline 8 & biz & 6 & 0.5 \\
\hline 9 & biz.pl & 1 & 0.1 \\
\hline 10 & net & 16 & 1.4 \\
\hline 11 & net.pl & 3 & 0.3 \\
\hline 12 & org & 3 & 0.3 \\
\hline 13 & nl & 1 & 0.1 \\
\hline 14 & regio & 18 & 1.6 \\
\hline 15 & inne & 214 & 19.3 \\
\hline Total number of ommercial & 903 & 80.6 \\
\hline Free of charge & 218 & 19.4 \\
\hline \multicolumn{2}{|c|}{ Total } & 1,221 & 100.0 \\
\hline
\end{tabular}

* Other national addresses in sub-domains.

(d) domain .pl with diacritic signs.

Source: author.

Obtained results are compatible with nationwide tendencies. According to NASK, in the first quarter of 2017, from among all active names in DNS (Domain Name System), $75.44 \%$ were registered directly in a domain of the highest level (.pl), 19.85\% in functional domains (e.g. .com.pl, .net.pl) and only $4.71 \%$ in regional domains (e.g. .waw.pl, .bialystok.pl). Domains with national diacritic signs made $1.49 \%$ of all names that were active in DNS (WIŚNIEWSKA-SKÓRA \& GNIADEK 2017).

10 addresses in the set of tested websites were noted in the domain agro.pl, i.e. the functional and national one of the second level (from the Latin for agriculture), intended for websites connected with agriculture. Addresses created as sub-domains for services offering accommodation were also numerous - 15 were noted in the domain afr.pl (offers of holidays at the seaside), 19 in agrowakacje.pl and 5 in agroturystyka.pl.

The owners of agrotourist farms relatively rarely use addresses of websites maintained (hosted) on free servers. 218 such cases were noted in the tested set (every fifth website) most of which were created in the domains republika.pl and interia.pl (Table 3). Addresses created as sub-domains of services cba.pl and pro.pl were slightly less popular although these service providers have been working for a relatively long time and are well-known on the market. Moreover, single addresses were noted as registered in the domains of .pl, piwko.pl, bloog.pl, ugu.pl, stronygratis.pl and 000web host.com. It was noticed that the owners of agrotourist farms more frequently chose alternative solutions in the form of a sub-domain created in the domain of a provider of hosting, regional (informational) portal or other. It is an indirect solution usually connected with hosting fees but excluding a subscription for the domain. What is more, a website maintained in such a way is free of advertisements (which are often found on free services).

Table 3. The number of addresses noted on free domains, separated into service providers

\begin{tabular}{|c|l|c|c|}
\hline \multirow{2}{*}{ No. } & \multirow{2}{*}{ Service provider } & \multicolumn{2}{|c|}{ Domains } \\
\cline { 3 - 4 } & & number & $\%$ \\
\hline 1 & republika.pl & 84 & 38.6 \\
\hline 2 & interia.pl & 58 & 27.6 \\
\hline 3 & cba.pl & 27 & 12.4 \\
\hline 4 & pro.pl & 16 & 7.3 \\
\hline 5 & za.pl & 9 & 3.6 \\
\hline 6 & friko.pl & 7 & 3.1 \\
\hline 7 & vgh.pl & 3 & 1.4 \\
\hline 8 & dzs.pl, like.pl & 2 & 0.9 \\
\hline 9 & weebly.com & 2 & 0.9 \\
\hline 10 & zafriko.pl & 2 & 0.9 \\
\hline 11 & wordpress.com & 2 & 0.9 \\
\hline 12 & remaining & 6 & 2.4 \\
\hline \multicolumn{2}{|c|}{ Total } & 218 & 100.0 \\
\hline
\end{tabular}

Source: author.

154 names (labels) with words (letters) separated with a hyphen were noted in the analysed set. Underlining was noted on four addresses - in every case they were created on free services. This is not recommended and rarely practiced, and is usually found on the addresses of amateur websites.

The addresses of agrotourist farms were most often created on the basis of keywords describing the character of a farm - the range of provided services or the attributes of its location and also the name or surname of the owner, the name of the location or the region. Moreover, the names of plants or animals were frequently used in addresses. Ten cases of placing the physical address of the farm (e.g. tymnikowo4.pl) were noticed too. The prefix 'agro': was noted in 179 addresses and the word 'agrotourism' (in Polish: 'agroturystyka') in 85 (usually in sub-domains). The words 'ranch' (in Polish: 'ranczo' or 'rancho' - 24 addresses), 'homestead' (in Polish: 'zagroda' - 14 addresses) and 'rooms' (in Polish: 'pokoje' - 10 addresses) were also found. In 50 cases, the prefix 'under' (in Polish: 'pod') in connection with a noun (e.g. birches, oaks, acacias, ash, maple, stork - in Polish: 'podbrzozami, poddebami, podakacjami, podjesionem, podklonem, podbocianem'. 
Table 4. Characteristics of agrotourist farm internet addresses according to their marketing potential

\begin{tabular}{|c|c|}
\hline Internet address & Comment \\
\hline pieniny-noclegi-debscy.eu & $\begin{array}{l}\text { Relatively long internet address. Great probability of making a mistake in the record. } \\
\text { Probably the name reserved due to keywords - Pieniny mountains, accommodation and } \\
\text { Dębscy (the farmer's name) in order for better positioning of the website in search results. }\end{array}$ \\
\hline wojciechówka.pl & $\begin{array}{l}\text { Uncommon address with diacritic signs. Not recommended due to the fact that users are } \\
\text { accustomed to names written without national characters. In this case, there is the website } \\
\text { of another tourist site under the address www.wojciechowka.pl. This can confuse users. }\end{array}$ \\
\hline chwf.pl & $\begin{array}{l}\text { Short and relatively simple name but means nothing and with no connotations. Deeper } \\
\text { analysis revealed that it comes from the first letters of the farm's name 'the hut in Fiedorow' } \\
\text { (in Polish: 'Chata w Fiedorowie'). It is easier for users to remember names that are composed } \\
\text { in a logical unit, with a determined meaning, formed of simple words (e.g. generic domains) } \\
\text { than sequences of signs without meaning. The address is not favourable in marketing terms. }\end{array}$ \\
\hline jp.trz.pl & $\begin{array}{l}\text { A name not associated with agrotourism. Analysis of the website suggests that it comes } \\
\text { from initials of the name and surname of the farm's owner. The website's subdomain } \\
\text { trz.pl - 'Trzcianka - fotografia cyfrowa' (digital photography). The address is not favourable } \\
\text { in marketing terms. }\end{array}$ \\
\hline chatamorgana.pl & $\begin{array}{l}\text { An interesting, 'catchy' name, easy to transfer orally and in writing and also to remember. } \\
\text { An address favourable in marketing terms. }\end{array}$ \\
\hline dworek.agro.pl & $\begin{array}{l}\text { Generic domain. Simple and at the same time significant internet address of agrotourist } \\
\text { offer of 'Dworek Baranó } w k a^{\prime} \text {. The address favourable in marketing terms. }\end{array}$ \\
\hline dolinaciszy.pl & $\begin{array}{l}\text { An address easy to speak, write and remember. Comprehensible and logical sequence. } \\
\text { Favourable in marketing terms. }\end{array}$ \\
\hline agrogawlik.itl.pl & $\begin{array}{l}\text { Subdomain, address in the domain itl.pl - hosting provider. Address created in such a way } \\
\text { does not need a subscription, however, it belongs to domain itl.pl. }\end{array}$ \\
\hline agrotyrystykalosien.manifo.com & $\begin{array}{l}\text { Website created by a creator and placed in the subdomain manifo.com. Its defect is the advert } \\
\text { banner of services provider. It does not need a subscription but does not belong to the farm. } \\
\text { The address is not favourable in marketing terms. }\end{array}$ \\
\hline vinixxx.republika.pl & $\begin{array}{l}\text { This internet address is difficult to pronounce or dictate. Subdomain - free hosting republika.pl } \\
\text { with obligatory advertisements. Not favourable in marketing terms. }\end{array}$ \\
\hline u-buraka.com & $\begin{array}{l}\text { Not a typical address though memorable. It comes from the name of the farmer who promotes } \\
\text { services as 'Agroturystyka u Buraka' (Agrotourism at Burak's place). Address in functional } \\
\text { domain of the highest level .com (from commercial) the domain of commercial businesses. }\end{array}$ \\
\hline podlasem.agroturystyka.bplaced.de & $\begin{array}{l}\text { Difficult to dictate the address in the subdomain a foreign server. Probably a selection of } \\
\text { hosting results from focusing the farm on German customers. An address not favourable } \\
\text { in marketing terms. }\end{array}$ \\
\hline
\end{tabular}

Source: author.

Frequently, the addresses indicated accommodation offered at someone's home, recorded as one sequence of characters i.e. 'uartura, uhalinki, ujanusza, uluizy, umarii, umichasi' etc. ('at Artur's place', 'at Halinka's' etc). 53 such addresses were noted. Addresses that consisted of a sequence of signs without any meaning or con-notation were found but this is not favourable in marketing terms (Table. 4).

\section{ADVANTAGES AND DISADVANTAGES OF PAYABLE AND FREE SERVICES}

Some owners of agrotourist farms choose budgetary solutions and use free hosting packages - data servers, software and internet addresses in the sub-domain. Although the quality of services is improving, their use often demands approval for publishing intrusive advertisements with content imposed by the provider of services in an imposed position. So, it is a specific cost for the user of services of such a type. Moreover, in using that sub-domain the user is branded by the service provider because the internet address of such a website is created in their domain and takes the form e.g. 'agroirena.republika.pl'. An address created in such a way is less attractive, it first of all informs the user that the website is on a free server and can have a less professional character. Websites placed on free services are usually just static visiting cards without advanced functionalities (KRÓL \& BEDLA 2014).

In general, free services are not accompanied by any guarantees of quality i.e. concerning constant access to services, data and applications. Loss of data as a result of changes in the rules of procedure or equipment failure is also possible (Table 5). In the case of registering free domains or aliases, the loss of address can be connected with the loss of time spent on building the brand on the internet. Moreover, offers of free hosting are often deprived of direct technical 
support and their usage can be connected with restricting parameters and resources. So, free hosting is most frequently used for maintaining amateur websites by those who are only gaining experience.

Table 5. Selected advantages and disadvantages of hosting packages with an internet address

\begin{tabular}{|c|c|}
\hline & \\
\hline 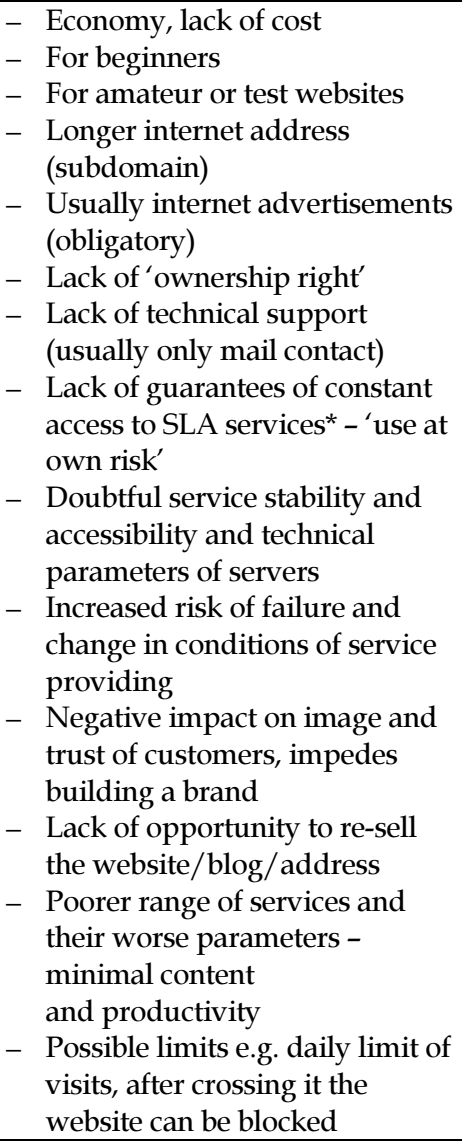 & $\begin{array}{l}- \text { Needs subscription } \\
- \text { Proper for profess- } \\
\text { ional, commercial } \\
\text { usages } \\
-\quad \text { Technical support } \\
\text { (phone contact) and } \\
\text { regular backup copies } \\
\text { of the server - files, } \\
\text { databases, mails } \\
- \text { The domain's name } \\
\text { depends only on the } \\
\text { registering person and } \\
\text { access to the market } \\
- \text { 'Ownership right' of } \\
\text { the domain } \\
-\quad \text { Lack of advertise- } \\
\text { ments } \\
- \text { SLA guarantees* } \\
\text { (services stability } \\
\text { and quality) } \\
- \text { Constant conditions of } \\
\text { accessing the service } \\
- \text { Possibility to resell the } \\
\text { address (website, blog) } \\
- \text { Usually high technical } \\
\text { quality of servers } \\
- \text { The range of business } \\
\text { - any }\end{array}$ \\
\hline
\end{tabular}

*Service Level Agreement (SLA).

Source: author.

\section{OBSERVATIONS, CONSIDERATIONS AND GUIDELINES}

At present, having so many available technical solutions - creators, editors and generators that allow a website to be built individually from ready components directly in a browser's window in a visual mode called WYSIWIG (What You See Is What You Get - the website will look like the one edited in the editor's programme) and are often connected with a hosting service. The temptation to prepare a website individually appears and is supported by service providers. Therefore, some agrotourist farms decide to choose the budgetary variant and they pick out a website created by means of creator in the free blog system or within a social media portal with a free address in a sub-domain. However, these are not business solutions and are treated as alternative or amateur which could not provide the basis for marketing campaigns to a lesser or even any extent (SMAGA 2015, WAWRYSZUK 2015). On the other hand, these solutions may be used by agrotourist farms to 'support' or complete the basic (main) website. However, composing unique content in such a way that they will be sufficient to be published in several services at the same time can be a challenge. So, the form of existence of a farm on the internet, taking into account the knowledge, skills, time and willingness of farmers, should be determined at this point.

These questions appeared during surveys whether the websites made accessible in the domain .pl are of better quality than these available in free domains (on free hosting accounts) as well as how to test this, particularly as the concept of 'website's quality' is complex and the quality itself is considered in many fields including technique, the form and range of presentation, or usability (KRÓL 2016b). So, the specific parameter or set of parameters which would serve as quality indexes should be selected. The quality of preparation of a website (technical and content) should be distinguished from its usability at this point. This, in turn, even with a well-produced website but placed on a free server can be conditioned by the extent of advertisements.

When discussing the choice of an address (hosting) between payable and free options, the relatively high costs of subscription are a frequently-heard argument. Paradoxically, this opinion was created by providers of the hosting services themselves who were offering attractive price promotions in the first year of using the service, whereupon the prices were raised in the following year. So, deciding to register a payable service, the costs of 'renewal of the domain' and hosting in following years should be analysed. Registering the domain 'on one's own account' is also an essential issue. Subscribers of a domain are fully entitled to dispose of it, so they can use it to start a domain with any content (according to law), 'redirect' it to another address or sell it on the secondary market. Therefore, when ordering the preparation of a website when registering a domain and buying the hosting package, its proper registration should be ensured so the owner of the farm or the firm would be its subscriber.

The internet address of an agrotourist farm should not be long. Its words should have the smallest number of diacritic signs (its record in the address bar of a browser will not require their transformation), moreover, it is not advisable to register a domain with diacritic signs (due to the habits of internet users and possible mistakes). Punctuation marks are not recommended either. Complicating the name can negat- 
ively influence the marketing potential of a website and limit its free use e.g. while dictating by telephone.

When selecting an address for a website whose contents are oriented at the Polish market, it is recommended to use Polish words only. Moreover, the main name should reflect the character of the business or uniqueness of the given entity.

\section{SUMMARY}

Selecting a domain can have a great impact on the efficiency of promotion on the internet. In spite of the fact that users most frequently reach information by means of search engines, the internet address does not become less relevant because it is often transmitted orally, placed on other internet pages and printed materials. It can also influence the place of a website in search results.

The surveys reveal that every fifth internet address was created in a sub-domain of a free service that was providing free hosting as well. It is a cost-free solution which, however, shows that farmers do not pay much attention to reaching customers by means of the internet or they choose their farm's promotion among offers of accommodation, in catalogues of websites and social media. However, each form of promotion refers to the farm's website which in a way 'makes the offer reliable'. The internet address is the specific address of a farm in the virtual world, the place where it can be 'visited', its surroundings can be seen and the decision about reserving an overnight stay can be made on this basis.

The number of farms which decided to have a website on a free server is not large, which negates the posed hypothesis. Much more frequently, farms use free subdomains - addresses established in the domains of payable providers of hosting services and also branded websites or various portals. It is a solution that reduces costs. However, the savings are virtual as the annual cost of subscription for the address in the domain .pl is now, depending on a registrar, about 50 PLN gross.

The internet address should be short, easy to pronounce and simple in writing. At the same time, it should be specific and easy to remember. Its selection should be appropriate for its target market and the character of the business. In Poland, the national domain is the most popular and registering on such a one is recommended. The popularity of the domain .eu, which still allows the registration of many attractive names, is growing as well. Domains .pl are identified with professionalism in contrast to free addresses - not many entities invest in a professional website and then place it on a free server deprived of quality warranty and technical support and which can be also connected with advertisements. Moreover, internet addresses in free domains and various subdomains can be associated with a website produced in an amateur way.

The selection of a domain and hosting package amounts to answering the question: what is the purpose of a farm's website. If farmers want to invest in a professional website prepared to attract customers, the address of which will be distributed on the internet and in printed materials, the choice of the payable option is recommended. The free address and hosting package with advertisements can call into question the image of the farm and negatively influence the website's perception. A well-chosen address in connection with a professional website assures message consistency and is the farm's property. On their basis, the brand can be built on the internet. However, when farmers possess a simple, amateur website which is not used for commercial purposes, they have few visits, its address is rarely used, the farm has only a small scale tourist business or they treat it as additional source of income, the free address and hosting package are acceptable. The loss of such an address will not cause image or financial losses.

\section{BIBLIOGRAPHY}

BARTOSIAK J., 2010, Rozstrzyganie sporów o nazwy domen internetowych, E-mantor, 1(33), pp. 73-76.

CHEN R., XU W., 2017, The determinants of online customer ratings: a combined domain ontology and topic text analytics approach, Electronic Commerce Research, 17(1), pp. 31-50, doi: 10. 1007/s10660-016-9243-6.

DROZDOWSKA M., DUDA-SEIFERT M., 2016, Turystyczne portale internetowe - wiarygodne źródło informacji?/Travel websites: a relevant source of statistical information?, Tourism/Turyzm, 26(2), pp. 7-14, doi: 10.18778/0867-5856. 26.2.01.

JANC K., 2015, Geografia domen internetowych - wybrane aspekty, Przegląd Geograficzny, 87(4), pp. 643-658, doi: 10.7163/ PrzG. $=2015.4 .4$.

KACHNIEWSKA M., 2011, Wpływ nowych technologii na rynek usług pośredników turystycznych, International Journal of Management and Economics, 32, pp. 239-258.

KRÓL K., 2015, Kalkulacja kosztów wykonania oraz promocji strony internetowej gospodarstwa agroturystycznego, Acta Scientiarum Pololnorum Formatio Circumiectus, 14(4), pp. 4148, doi: 10.15576/ ASP.FC/2015.14.4.41.

KRÓL K., 2016a, Globalne zmiany technologiczne i ich wpływ na promocję agroturystyki w Internecie, Roczniki Naukowe Ekonomii Rolnictwa i Rozwoju Obszarów Wiejskich, 103(3), pp. 84100.

KRÓL K., 2016b, Wpływ optymalizacji witryn internetowych na promocję turystyki wiejskiej w sieci, Problemy Drobnych Gospodarstw Rolnych - Problems of Small Agricultural Holdings, 3, pp. 57-71, doi: 10.15576/PDGR/2016.3.57.

KRÓL K., BEDLA D., 2014, Ocena witryn internetowych gospodarstw agroturystycznych, Marketing i Rynek, 11, pp. 22-29. 
KRÓL K., WOJEWODZIC T., 2006, Strona internetowa źródłem przewagi konkurencyjnej gospodarstwa agroturystycznego, Wieś i Doradztwo, 1-2(45-46), pp. 59-62.

KRÓL K., ZDONEK D., GORZELANY J., 2017, Wartość informacyjna domeny internetowej, Marketing i Rynek, 3, pp. 24-32.

KRZYŻANOWSKA K., 2014, Skuteczność działań informacyjnopromocyjnych w turystyce wiejskiej, Zeszyty Naukowe Uniwersytetu Szczecińskiego. Ekonomiczne Problemy Turystyki, 3(27), pp. 41-55.

LINDENTHAL T., 2014, Valuable words: The price dynamics of internet domain names, Journal of the American Society for Information Science and Technology, 65(5), pp. 869-881, doi: 10.1002/asi.23012.

PAWLAK J., 2014, Wykorzystanie nowych domen internetowych najwyższego rzędu jako narzędzia promocji mikro i małego przedsiębiorstwa, Zeszyty Naukowe Uniwersytetu Szczecińskiego. Ekonomiczne Problemy Ustug, 111: Uwarunkowania rynkowe rozwoju mikro, matych $i$ średnich przedsiębiorstw, pp. 521530.

ROGOWSKI M., 2014, Arbitraż w przedmiocie nazw domen internetowych na podstawie Uniform Domain Resolution Policy, Rynek - Społeczeństwo - Kultura, 2 (10), pp. 12-20.
SHANG S.S., WU Y.L., SIĘ Y.J., 2017, Generating consumer resonance for purchase intention on social network sites, Computers in Human Behavior, 69, pp. 18-28, doi: 10.1016/ j.chb.2016.12.014.

SMAGA M., 2015, Czym w tym roku zaskoczy cię Google? „Raporty interaktywnie.com. Marketing w wyszukiwarkach", pp. 42-49, https:/ / goo.gl/HBWoZ9; 21.06.2017.

WAWRYSZUK R., 2015, Recepta na sukces? Trafna domena i krajowe rozszerzenie. „Raporty interaktywnie.com. Domeny, hosting, chmura", pp. 25-31, https://goo.gl/tXbEs4; 21.06. 2017.

WIŚNIEWSKA-SKÓRA A., 2016, Rynek nazw domeny .pl. Szczegótowy Raport NASK za czwarty kwartat 2016 roku, https://goo.gl/ EtxobZ; 12.06.2017.

WIŚNIEWSKA-SKÓRA A., GNIADEK A., 2017, Rynek nazw domeny .pl. Szczegótowy raport NASK za pierwszy kwartat 2017 roku, https://goo.gl/Zs8NQo; 21.06.2017.

ZHU F., ZHANG X., 2010, Impact of online consumer reviews on sales: The moderating role of product and consumer characteristics, Journal of Marketing, 74(2), pp. 133-148, doi: 10.1509/ jmkg. 74.2.133.

Article received:

28 June 2017

Accepted:

24 July 2017 